\title{
Faktor-Faktor yang Mempengaruhi Konsumsi Sayur-Sayuran Di Kabupaten Hulu Sungai Utara Provinsi Kalimantan Selatan
}

\section{(Factors Affecting Vegetable Consumption in Hulu Sungai Utara Regency South Kalimantan Province)}

\author{
Heldawati \\ Program Studi Agribisnis, Sekolah Tinggi Ilmu Pertanian Amuntai \\ heldawati006@gmail.com
}

\begin{abstract}
ABSTRAK
Penelitian ini bertujuan untuk mengukur jumlah konsumsi sayuran rumah tangga di pedesaan dan perkotaan, dan untuk menganalisis faktor-faktor yang mempengaruhi konsumsi sayuran rumah tangga di daerah pedesaan dan perkotaan di Kabupaten Hulu Sungai Utara Provinsi Kalimantan Selatan. Penelitian dilakukan di Februari - Juli 2014 di Kecamatan Amuntai Tengah dengan memilih tiga desa dengan kriteria pedesaan yaitu Desa Pinang Habang, Danau Carmin dan Tigarun, dan tiga desa dengan kriteria perkotaan yaitu Sungai Malang, Tangga Ulin Hulu dan Pelampitan Hilir. Metode multistage sampling dengan random sampling diterapkan. Analisis data menggunakan regresi linier berganda. Hasil penelitian menunjukkan bahwa konsumsi sayuran di perkotaan lebih besar daripada konsumsi sayuran di pedesaan. Konsumsi sayuran di daerah pedesaan dan perkotaan di Hulu Sungai Utara lebih rendah dari standar nutrisi yang direkomendasikan dari Pola Makanan Harapan (PPH) pemerintah yaitu 250 gram / kapita / hari. Faktor-faktor yang mempengaruhi konsumsi sayuran pedesaan dan perkotaan adalah kepemilikan rumah tangga Di Hulu Sungai Utara adalah ukuran keluarga, pengetahuan gizi ibu, preferensi untuk sayuran dan tipologi daerah (desa / kota). Di sisi lain, pendapatan keluarga tidak memengaruhi konsumsi sayuran rumah tangga.
\end{abstract}

Kata kunci : Konsumsi, sayuran, perkotaan, perdesaan, rumah tangga.

\section{ABSTRACT}

This study aims to measure the amount of consumption of household vegetables in rural and urban areas, and to analyze the factors that affect consumption of household vegetables in rural and urban areas in North Hulu Sungai Regency, South Kalimantan Province. The study was conducted in February - July 2014 in Central Amuntai Subdistrict by selecting three villages with rural criteria, namely Pinang Habang Village, Lake Carmin and Tigarun, and three villages with urban criteria namely Malang River, Upper Ulin and Downstream Turning Stairs. The multistage sampling method with random sampling is applied. Data analysis using multiple linear regression. The results showed that vegetable consumption in urban areas was greater than the consumption of vegetables in rural areas. Vegetable consumption in rural and urban areas in North Hulu Sungai is lower than the recommended nutritional standard of the government Food Pattern (PPH), which is 250 grams / capita / day. The factors that influence rural and urban vegetable consumption are ownership of households in the North River is family size, knowledge of maternal nutrition, preference for vegetables and regional typology (village / city). On the other hand, family income does not affect the consumption of household vegetables.

Keywords: Consumption, vegetables, urban, rural, household.

\section{PENDAHULUAN}

Pangan merupakan kebutuhan dasar yang merupakan hak setiap manusia dan merupakan salah satu faktor penentu bagi kualitas sumberdaya manusia. Pangan adalah sumber energi utama manusia untuk melakukan segala macam aktivitasnya. Pangan atau makanan, baik secara langsung ataupun tidak langsung awalnya berasal dari tumbuhan. Tumbuhan merupakan salah satu dari sedikit makhluk hidup yang mampu memanfaatkan energi dari matahari (Badan Ketahanan Pangan Provinsi Kalimantan Selatan, 2012).

Menurut Rubatzky dan Yamaguchi (1998), dari sekian banyak jenis tanaman yang dijadikan sebagai bahan pangan, sayuran memiliki kelompok yang paling 
banyak dimanfaatkan karena pada sayur terdapat kandungan-kandungan gizi yang dibutuhkan oleh tubuh manusia.

Sayur sangat penting dalam menu makanan seimbang, hal ini karena sayuran adalah salah satu kelompok komoditas pangan yang banyak mengandung sumber vitamin dan mineral yang merupakan unsur penting untuk kesehatan manusia. Vitamin yang ada di sayuran antara lain provitamin A, vitamin $\mathrm{C}, \mathrm{K}, \mathrm{E}$ dan barbagai vitamin $\mathrm{B}$ kompleks, disamping itu juga kaya akan berbagai jenis mineral diantaranya kalium, kalsium, zat besi, magnesium, mangan, seng dan selenium. Vitamin dan mineral juga memegang peranan penting dalam hal fungsinya untuk kecerdasan (Soekartawi, 1987).

Berdasarkan Undang-undang No. 13 Tahun 2010 pasal 95 tentang hortikultura, mengamanatkan bahwa komoditas sayuran dan buah bukan hanya sebagai pendamping pangan pokok melainkan tergolong sebagai pangan utama yang harus dikonsumsi masyarakat setiap harinya. Selain itu juga menetapkan bahwa pencapaian angka konsumsi sayur dan buah per kapita setiap tahunnya berdasarkan pada standar kesehatan, yang dalam perencanaan konsumsi pangan sejalan dengan standar komposisi Pola Pangan Harapan (PPH) (BP4K2P Kabupaten Hulu Sungai Utara, 2012).

Standar konsumsi sayur dan buah berdasarkan komposisi Pola Pangan Harapan yaitu sebanyak 250 gram/kapita/hari. Karena kondisi pola konsumsi sayur dan buah penduduk Indonesia saat ini masih rendah, sehingga perlu upaya peningkatan konsumsi sayur dan buah bagi seluruh masyarakat, diantaranya melalui pendidikan formal (kurikulum pendidikan) maupun melalui sosialisasi secara berkelanjutan kepada seluruh masyarakat (BP4K2P Kabupaten Hulu Sungai Utara, 2012)

Kabupaten Hulu Sungai Utara merupakan salah satu kabupaten yang rawan pangan di Indonesia. Rawan pangan dapat terjadi di antaranya terkait masalah produksi, terutama terkait dengan daya beli masyarakat, akses terhadap pangan yang terbatas dan kekurangan kalori. Masalah ketahanan pangan juga dapat ditinjau dari sisi perwilayahan, misalnya ketahanan pangan kawasan perdesaan dan perkotaan (BP4K2P Kabupaten Hulu Sungai Utara, 2012).

Peningkatan produksi sayur-sayuran diharapkan dapat meningkatkan konsumsi sayur-sayuran. Menurut data BP4K2P Kabupaten Hulu Sungai Utara (2012), untuk tingkat konsumsi sayur-sayuran di Kabupaten Hulu Sungai Utara berdasarkan PPH adalah 100 gram/hari. Tingkat konsumsi ini masih sangat rendah dari anjuran pemerintah untuk standar konsumsi sayursayuran.

Tujuan penelitian ini adalah (i) mengukur besarnya konsumsi sayur-sayuran tingkat rumah tangga wilayah perdesaan dan perkotaan di Kabupaten Hulu Sungai Utara (ii) menganalisis faktor-faktor sosial, budaya dan ekonomi yang mempengaruhi konsumsi sayur-sayuran rumah tangga di Kabupaten Hulu Sungai Utara.

\section{METODE PENELITIAN}

\section{Lokasi dan Waktu Penelitian}

Penelitian ini dilaksanakan di Kecamatan Amuntai Tengah Kabupaten Hulu Sungai Utara, dimulai bulan Nopember 2013 - Januari 2014.

\section{Metode Penarikan Contoh}

Pengambilan contoh dilakukan dengan metode multistage random sampling dimana pemilihan contoh dilakukan dengan beberapa tahap secara acak.

1. Tahap Pertama, secara acak memilih 3 desa dari 16 kelurahan/desa kriteria perkotaan dan 3 desa dari 13 kelurahan/ desa kriteria perdesaan. Untuk 3 desa kriteria perkotaan terpilih Sungai Malang, Tangga Ulin Hulu, dan Palampitan Hilir. Sedangkan 3 desa kriteria perdesaan terpilih Pinang Habang, Danau Carmin dan Tigarun.

2. Tahap Kedua, dari 3 desa kriteria perkotaan dan 3 desa kriteria perdesaan diambil secara acak 2 rukun tetangga (RT), sehingga masing-masing berjumlah $6 \mathrm{RT}$ dari desa kriteria perkotaan dan $6 \mathrm{RT}$ dari desa kriteria perdesaan 
3. Tahap ketiga, masing-masing RT yang terpilih secara acak diambil 10 ibu rumah tangga, jadi jumlah responden untuk desa kriteria perkotaan sebanyak 60 responden dan jumlah responden untuk desa kriteria perdesaan sebanyak 60 responden.

\section{Analisis Data}

Data yang diperoleh ditabulasi kemudian dianalisis secara deskriptif dan uji statistik. Semua data kuantitatif kemudian akan dianalisis secara statistic dengan menggunakan computer dan program yang digunakan adalah SPSS vers 21 .

Untuk menjawab tujuan pertama yaitu mengukur besarnya konsumsi sayur-sayuran rumah tangga wilayah perdesaan dan perkotaan di Kabupaten Hulu Sungai Utara menggunakan metode analisis tabulasi sederhana dimana konsumsi sayur-sayuran dalam besaran nilai gram/kapita/bulan atau gram/kapita/hari maupun dalam bentuk persentase.

Untuk menjawab tujuan kedua yaitu menguji faktor-faktor apa saja yang secara nyata mempengaruhi konsumsi sayursayuran menggunakan analisis multivariat yaitu metode regresi linear berganda. Model analisis yang dibangun untuk konsumsi sayur-sayuran di Kabupaten Hulu Sungai Utara adalah sebagai berikut :

$$
\begin{aligned}
C= & a+\beta_{1} X_{1}+\beta_{2} X_{2}+\beta_{3} X_{3}+\beta_{4} X_{4}+ \\
& \beta_{5} D_{1}+\varepsilon
\end{aligned}
$$

dimana :

$$
\begin{aligned}
& \mathrm{C}=\begin{array}{l}
\text { Konsumsi sayur-sayuran rumah tangga } \\
\text { (gram/kapita/hari) }
\end{array} \\
& \text { a }=\text { Konstanta } \\
& \beta_{1-5}=\text { Koefisien regresi untuk masing- }
\end{aligned}
$$

masing faktor yang diamati

$$
\begin{aligned}
\varepsilon & =\text { Kesalahan acak } \\
\mathrm{X}_{1} & =\text { Ukuran keluarga } \\
\mathrm{X}_{2} & =\text { Pengetahuan gizi ibu } \\
\mathrm{X}_{3} & =\text { Preferensi terhadap sayur-sayuran } \\
\mathrm{X}_{4} & =\text { Penerimaan rumah tangga } \\
\mathrm{D}_{1} & =\text { kondisi geografis } \\
& =1: \text { daerah perkotaan } \\
& =0: \text { daerah perdesaan }
\end{aligned}
$$

Untuk mengetahui signifikasi model yang dibangun diatas dapat diketahui dari penjelasan statistik dari output analisis yaitu nilai $\mathrm{F}$ ( $\mathrm{F}$ value) observasi atau $\mathrm{F}$ hitung dengan $\mathrm{F}$ tabel (dilihat dari tabel probabilitas t). Kriteria pengujian adalah sebagai berikut:

1. Jika $F$ hit $\leq F$ tabel berarti signifikan atau $\mathrm{H}_{0}$ diterima, berarti variabel bebas secara bersama-sama tidak berpengaruh nyata terhadap konsumsi sayur-sayuran rumah tangga di Kabupaten Hulu Sungai Utara.

2. Jika F hit $>\mathrm{F}$ tabel berarti tidak signifikan atau $\mathrm{H}_{1}$ diterima, berarti variabel bebas secara bersama-sama berpengaruh nyata terhadap konsumsi sayur-sayuran di Kabupaten Hulu Sungai Utara.

\section{HASIL DAN PEMBAHASAN}

\section{Jumlah Sayur-sayuran yang dikonsumsi}

Banyaknya sayur-sayuran yang dikonsumsi rumah tangga sampel di wilayah perdesaan adalah rata-rata sebesar 7043,33 gram/bulan atau 51,93 gram/kapita/hari. Sedangkan di wilayah perkotaan adalah ratarata sebesar 9377,02 gram/bulan atau 72,58 gram/kapita/hari. Angka ini ternyata lebih kecil dari standar gizi yang dianjurkan pemerintah yaitu 250 gram/kapita/hari. Rendahnya jumlah konsumsi sayur-sayuran tersebut diduga oleh rendahnya tingkat pendidikan dan pengetahuan gizi.

\section{Faktor-Faktor yang Mempengaruhi Konsumsi Sayur-sayuran Wilayah Perdesaan dan Perkotaan di Kabupaten Hulu Sungai Utara}

\section{Koefisien Determinasi}

Berdasarkan hasil analisis regresi, besarnya koefesien determinasi sebesar 0,399 yang artinya persentase sumbangan pengaruh variabel independen terhadap variabel dependen sebesar 39,9\% sedangkan sisanya sebesar $60,1 \%$ dipengaruhi oleh variabel lain yang tidak dimasukkan dalam model ini. Nilai $R^{2}$ dapat dilihat pada Tabel 1 . 
Tabel 1. Nilai koefisien determinasi

\begin{tabular}{clcccc}
\hline Model & R & R Square & Adjusted R Square & Std. Error of the Estimate & Durbin-Watson \\
\hline 1 & $.632^{\mathrm{a}}$ & .399 & .373 & 28.95715 & 1.606
\end{tabular}

a. Predictors: (Constant), Penerimaan RT, Preferensi, Ukuran Keluarga, Dummy, Pengetahuan Gizi IRT

b. Dependent Variable: Konsumsi Sayuran

\section{Uji F}

Uji F digunakan untuk menguji signifikansi pengaruh beberapa variabel independen terhadap variabel dependen secara bersamasama. Untuk pengambilan keputusan jika nilai signifikansi $<0,05$ maka kesimpulannya ada pengaruh antara variabel independen terhadap variabel dependen, sedngkan jika nilai signifikansi > 0,05 maka tidak ada pengaruh antara variabel independen terhadap variabel dependen. Hasil uji regresi nilai signifikansi adalah 0,000 jadi dapat diambil kesimpulkan ada pengaruh secara bersama-sama antara ukuran keluarga, pengetahuan gizi ibu rumah tangga, preferensi terhadap sayur-sayuran, kondisi geografis (desa/kota) dan penerimaan rumah tangga terhadap konsumsi sayur-sayuran. Hasil analisis uji F dapat dilihat pada Tabel 2.

Tabel 2. Hasil Analisis Uji F.

\begin{tabular}{llrrrrr}
\hline & Model & Sum of Squares & Df & Mean Square & F & Sig. \\
\cline { 1 - 6 } 1 & Regression & 63560.393 & 5 & 12712.079 & 15.160 & $.000^{\mathrm{b}}$ \\
& Residual & 95590.908 & 114 & 838.517 & & \\
& Total & 159151.301 & 119 & & & \\
\hline
\end{tabular}

Setelah uji statistik (uji F) diperoleh F hitung sebesar 12,552 dan F tabel sebesar 2,295 (tingkat signifikasi 0,05). Berdasarkan hasil diatas kriteria pengujian yang sesuai adalah menolak Ho (F hitung $>$ F tabel). Jadi dapat disimpulkan bahwa ukuran keluarga, pengetahuan gizi ibu rumah tangga, preferensi terhadap sayur-sayuran, penerimaan rumah tangga dan kondisi geografis (desa/kota) secara bersama-sama berpengaruh terhadap konsumsi sayursayuran

\section{Uji t}

Berdasarkan hasil analisis regresi faktorfaktor yang mempengaruhi konsumsi sayursayuran wilayah perdesaan dan perkotaan diperoleh nilai yang ditunjukkan pada Tabel 3 .

Tabel 3. Hasil Analisis regresi Faktor-faktor yang Mempengaruhi Konsumsi sayur-sayuran Wilayah perkotaan dan perdesaan dan Perkotaan di Kabupaten Hulu Sungai Utara Tahun 2014.

\begin{tabular}{|c|c|c|c|c|}
\hline \multirow{2}{*}{$\begin{array}{l}\text { Faktor-faktor yang mempengaruhi } \\
\text { Konsumsi sayur-sayuran }\end{array}$} & \multicolumn{3}{|c|}{ Koefisien } & \multirow{2}{*}{$\begin{array}{c}\text { Keterangan } \\
\mathrm{p}<0,05\end{array}$} \\
\hline & $\mathrm{B}$ & $\mathrm{T}$ & $\mathrm{P}$ & \\
\hline Konstanta & $-12,115$ & $-0,653$ & 0.515 & \\
\hline Faktor sosial: & & & & \\
\hline a. Ukuran keluarga & $-3,761$ & $-2,086$ & 0,039 & Signifikan \\
\hline $\begin{array}{l}\text { b. Pengetahuan gizi ibu rumah tangga } \\
\text { Faktor budaya: }\end{array}$ & 0,932 & 3,174 & 0,002 & Signifikan \\
\hline a. Preferensi terhadap sayur-sayuran & 14,902 & 3,005 & 0,003 & Signifikan \\
\hline $\begin{array}{l}\text { b. Kondisi geografis (Desa/Kota) } \\
\text { Faktor ekonomi }\end{array}$ & 14,516 & 2,633 & 0,010 & Signifikan \\
\hline
\end{tabular}




\section{\begin{tabular}{lllll} 
a. Penerimaan rumah tangga & $0,002 \times 10^{-3}$ & 0,381 & 0,704 & Tidak Signifikan \\
\hline
\end{tabular}}

\section{Faktor sosial}

a. Ukuran keluarga

Ukuran keluarga berpengaruh negatif terhadap konsumsi sayur-sayuran pada wilayah perdesaan dan perkotaan yang ditunjukkan oleh hasil analisis regresi yang menunjukkan nilai $\mathrm{t}=-2,086$ dengan $\mathrm{p}=0,039$. Berdasarkan pada analisis tersebut ukuran keluarga ternyata merupakan faktor penentu yang mempengaruhi konsumsi sayur-sayuran.

b. Pengetahuan Gizi Ibu Rumah Tangga

Berdasarkan hasil analisis regresi menunjukkan nilai $\mathrm{t}=3,174$ dengan $\mathrm{p}=$ 0,002. Dengan demikian dapat disimpulkan ada pengaruh positif secara parsial antara pengetahuan gizi ibu rumah tangga dengan konsumsi sayur-sayuran.

\section{Faktor Budaya}

a. Preferensi terhadap sayur-sayuran

Preferensi terhadap sayur-sayuran adalah sebesar 93,33\% di wilayah perdesaan pada kategori menyukai, sedangkan di wilayah perkotaan sebesar $96,67 \%$ pada kategori menyukai. Berdasarkan hasil analisis regresi, peubah preferensi terhadap sayur-sayuran berpengaruh sangat nyata terhadap jumlah konsumsi sayur-sayuran, yang ditunjukkan dengan nilai $\mathrm{p}=0,003$ dan $\mathrm{t}=3,005$.

b. Kondisi Geografis

Berdasarkan hasil analisis regresi menunjukkan bahwa $\mathrm{t}=2,633$ dengan $\mathrm{p}=$ 0,010. Hal ini dapat disimpulkan bahwa tempat tinggal mempunyai hubungan yang signifikan atau berpengaruh sangat nyata dengan konsumsi sayur-sayuran.

\section{Faktor Ekonomi}

a. Penerimaan rumah tangga

Penerimaan disini adalah gabungan antara penerimaan baik yang berasal dari suami dan isteri.Sumber penerimaan rumah tangga yang diperoleh dari jenis pekerjaan seperti PNS, pensiunan PNS, petani, nelayan, pedagang, pengrajin anyaman, ojek dan lain-lain.Penerimaan rumah tangga rata-rata di wilayah perdesaan adalah sebesar Rp 970.833,33. Sedangkan penerimaan rumah tangga rata-rata di wilayah perkotaan adalah sebesar $\mathrm{Rp}$ 1.259.166,67.

Berdasarkan hasil analisis regresi menunjukkan penerimaan rumah tangga tidak ada pengaruh secara parsial dengan konsumsi sayur-sayuran rumah tangga.Penerimaan rumah tangga ternyata bukan merupakan faktor penentu dalam konsumsi sayur-sayuran.

Hasil regresi linear berganda yang diperoleh dapat dirumuskan dalam bentuk persamaan regresi sebagai berikut:

$C=-12,115-3,761 X_{1}+0,932 X_{2}+$

$14,902 X_{3}+\left(0,002 \times 10^{-3}\right) X_{4}+$

$14,516 D_{1}+\varepsilon$

Peningkatan konsumsi sayur-sayuran dapat dilakukan dengan meningkatkan pengetahuan gizi ibu rumah tangga melalui penyuluhan kesehatan terkait upaya perbaikan gizi masyarakat, meningkatkan preferensi terhadap sayuran dengan membuat bermacam-macam olahan sayuran agar menarik selera anggota keluarga dan menerapkan kebiasaan makan sehat seperti sayur bagi anak-anak usia dini serta memanfaatkan lahan pekarangan dengan menanam tanaman sayuran yang cocok dengan tempat tinggal baik itu di wilayah perdesaan maupun perkotaan.

\section{KESIMPULAN}

Banyaknya konsumsi sayur-sayuran rumah tangga di wilayah perdesaan dan perkotaan dapat dikatakan rendah, karena jumlah konsumsi sayur-sayuran lebih kecil dari standar gizi yang dianjurkan pemerintah yaitu 250 gram/kapita/hari. Faktor-faktor yang berpengaruh nyata terhadap konsumsi sayur-sayuran rumah tangga baik wilayah perdesaan dan perkotaan di Kabupaten Hulu Sungai Utara adalah ukuran keluarga, pengetahuan gizi ibu rumah tangga, preferensi terhadap sayur-sayuran dan kondisi geografis (desa/kota). Sedangkan penerimaan rumah tangga tidak berpengaruh secara nyata terhadap konsumsi sayursayuran. 


\section{DAFTAR PUSTAKA}

Badan Ketahanan Pangan Provinsi Kalimantan Selatan. 2012. Analisis Kebutuhan Konsumsi Pangan Provinsi Kalimantan Selatan. Banjarbaru.
BP4K2P Kabupaten Hulu Sungai Utara. 2012. Laporan Pola Pangan Harapan (PPH) Tingkat Ketersedian Pangan. Amuntai.

Rubatzky,V.E dan Yamaguchi. 1998. Sayuran Dunia, Prinsip, Produksi, dan Gizi. ITB. Bandung. 